\title{
Health Status of Women Workers Involved in Cashew Processing Units in Konkan Region of Maharashtra, India
}

\author{
Geetanjali Waikar $^{1 *}$ and Suman Singh ${ }^{2}$ \\ ${ }^{1}$ SMS, Home Science, KVK, Lanja, Ratnagiri (M.S) and PhD scholar, FRM, COHSC, \\ MPUAT, Udaipur, India \\ ${ }^{2}$ Department of Resource Management and Consumer Science, COHSC, MPUAT, \\ Udaipur, India
}

*Corresponding author

\section{A B S T R A C T}

\section{Keywords}

Health status, BMI, $\mathrm{VO}_{2}$ max, Blood Pressure

Article Info

Accepted:

10 July 2018

Available Online:

10 August 2018
India is the largest producer of raw cashew nut contributing $20 \%$ of total global production. The production and productivity of cashew is highest in the state of Maharashtra. A sample of 120 women working in cashew processing units were selected for the present study from Raigad and Ratnagiri district of Maharashtra state belonging to age group 25 to 45 years having 5 years work experience. Physical fitness and health have a harmonious relationship and health of the working population denotes productivity of the nation and therefore knowledge of physical fitness and its application is of prime importance. Physical characteristics of subjects were assessed by recording age, height, weight, Body Mass Index (BMI), $\mathrm{VO}_{2}$ max and also recorded blood pressure of selected respondents. The mean age of all the women workers was 33.65 years, mean weight was $45.96 \mathrm{~kg}$ with $153.27 \mathrm{~cm}$ height. The mean of the $\mathrm{VO}_{2}$ max of the respondents was 36.98 and the Body Mass Index (BMI) was 19 which can be considered in normal category respectively.

\section{Introduction}

In India cashew is being grown in an area of 10.27 lakh hectares with a total production of 7.25 lakh MT of raw nuts and unit area productivity of $706 \mathrm{~kg} / \mathrm{ha}$. India is the largest producer of raw cashew nut contributing 20\% of total global production. The major distribution of Cashew in India is in the States of Kerala, Karnataka, Goa, and Maharashtra along the West Coast, Tamil Nadu, Andhra Pradesh, and Orissa along the East Coast and some extent in the states of West Bengal,
Chhattisgarh, Gujarat, Jharkhand and North Eastern States. The production and productivity of cashew is highest in the state of Maharashtra. The highest average productivity of Maharashtra is $1262 \mathrm{Kg} / \mathrm{ha}$. Maharashtra is the leading state of cashew nut production in India. They produce 24.02 per cent of total production from India.

Andhra Pradesh and Orissa are the other two States in the $2^{\text {nd }}$ and $3^{\text {rd }}$ position followed by Maharashtra in the production of cashew in India. http://dccd.gov.in 
Physical fitness comprises two related concepts: general or static fitness i.e. a state of health or well-being and specific dynamic fitness i.e. related to task-oriented fitness. Physical fitness has three main aspects. These are static fitness (absence of diseases), dynamic fitness (ability to perform strenuous work) and motor skill fitness. Of these three, the dynamic fitness is very important for cashew unit women worker, this study was designed to know physical characteristics and physical fitness of women worker involved in cashew nut units. Physical fitness and health have a harmonious relationship and health of the working population denotes productivity of the nation and therefore knowledge of physical fitness and its application is of prime importance.

\section{Materials and Methods}

Sample of 120 healthy women working in cashew processing units were selected for the present study from Raigad and Ratnagiri district of Maharashtra state belonging to age group of 25 to 45 years having 5 years work experience.

Physical characteristics were assessed by recording height, weight by using anthropometric kit. Body mass index (BMI), $\mathrm{VO}_{2}$ max was calculated for each women worker and also recorded blood pressure of selected respondents.

\section{Assessment of health status}

The physical fitness of the selected sample was studied through Body Mass Index (BMI) method as per the classification of Garrow (1994). The BMI of the subjects was calculated by using their height and weight data.

$$
\text { BMI }\left(\frac{\mathbf{k g}}{\mathbf{m}^{2}}\right)=\frac{\text { Weight }(\mathrm{kg})}{\operatorname{Height}^{2}(\mathbf{m})}
$$

The obtained data was categorized with the following Body Mass Index classification given by Garrow (1994)

\section{BMI class Presumptive diagnosis}

16.0 - * CED Gr. III (Severe)

16.0 - 17.0 - * CED Gr. II (Moderate)

17.0 - 18.5 - * CED Gr. I (Mild)

18.5 - 20 - Low weight normal

20 - 25.0 - Weight normal

25.0 - 30.0 - Obese (Grade I)

Above 30.0 - Obese (Grade II)

(*CED stands for chronic energy deficiency)

\section{$\mathrm{VO}_{2} \mathrm{Max}$}

The $\mathrm{VO}_{2}$ Max was calculated to evaluate the physical condition of the individual workers.

The physical fitness of selected sample was studied through this method as per classification by Varghese et al., (1994).

The formula is based on the relationship between age and body weight as they have great influence on $\mathrm{VO}_{2}$ max. Age of the subject was also recorded.

$\mathrm{VO}_{2} \operatorname{Max}(\mathrm{l} / \mathrm{min})=.0.023 \mathrm{x}$ Body Weight $(\mathrm{kg})$ -0.034 x Age (yr.) +1.652

$\operatorname{V02Max}(\mathrm{ml} / \mathrm{kg}) / \mathrm{min}.)=\frac{\operatorname{V02Max}(\mathrm{l} / \mathrm{min} .) \mathrm{x1000}}{\text { Bodyweight }(\mathrm{kg})}$

Interpretation of $\mathrm{VO}_{2}$ scores to determine health status

VO2Max (ml/kg/min) - Health Status

Upto 15.0 - Poor

16.0-25.0 - Low Average

26.0 -30.0 - High Average

31.5-40.0 - Good

41.0-45.0 - Very Good

Beyond 45 - Excellent 


\section{Blood pressure}

Blood pressure measurements were collected by using an automatic and validated blood pressure device (Omron-model HEM 705CP). Systolic and diastolic blood pressures were recorded respectively; the average of three readings was used in data analysis.

\section{Results and Discussion}

\section{Physical characteristics of cashew processing women workers}

Physical characteristics of the women worker involved in cashew nut factory are presented in the Table 1 and it revealed that the mean age of the women workers was 33.65 years, mean weight was $45.96 \mathrm{~kg}$ with $153.27 \mathrm{~cm}$ height. The mean of the $\mathrm{VO} 2$ max of the respondents was $36.98 \mathrm{ml} / \mathrm{kg} / \mathrm{min}$ and the Body Mass Index (BMI) was 19 which can be considered as normal category (Table 1). Borah et.al, 2001 also found BMI of rural women of Assam involved in the activity of sun drying of grain to be 19.8 which was also in normal category.

\section{Body Mass Index (BMI)}

Six cashew processing activities were selected such as Cutting of cashew shell, shelling of cashew nut, drying and cooling of kernel, peeling of kernel, grading of kernel, and Packing of kernel. Data of respondents as per cashew processing activities was compared with the body mass index and depicted in table 2. Data revealed that very few respondents that is 50 percent respondents working in cutting of cashew shell were in class of normal category. While $35 \%$ respondents were in chronic energy deficiency mild and few respondents were in chronic energy deficiency (15\%). Whereas majority of respondents working in cashew processing activities had their normal weight in shelling of cashew nut
$(60 \%)$. While in drying and cooling of kernel $70 \%$ of the respondents have normal weight. In the activity grading of kernel and Packing of kernel 65 percent respondents were in normal weight category and in peeling of kernel 50 percent i.e. half of the respondents were in normal weight category. Very less number i.e.10 percent respondents in shelling of cashew nut were in severe chronic energy deficiency, mild chronic energy deficiency, moderate chronic energy deficiency, and in the category of obese grade one. Results from the study of Kishtwaria and Aruna (2007) were similar to the results of present research, also found that hill farm women of Himachal Pradesh had normal BMI $(22.85 \pm 3.91)$. In this study the results were contradictory as reported by Ranjwan and Zend (2007) also informed that physical fitness and BMI of the majority of women subjects was below average in unorganized and self-employed sector. BMI Borah et al., (2016) revealed that the 2.5 percent of women worker belonged to Chronic Energy Deficiency Grade II (Moderate), 20 percent of them belonged to Chronic Energy Deficiency Grade I (Mild) and 77.5 percent of women worker belonged to normal weight category these results were in line with the present study.

Respondents in peeling of kernel (20\%), were found in the category of severe chronic energy deficiency, few respondents were categorized in mild chronic energy deficiency (10\%), and $10 \%$ of women workers were found, in the moderate chronic energy deficiency and 5 percent respondents were in obese grade one category of body mass index. Thus it can be concluded that most of the respondents were having good nutritional status which connotes that they had good working capacity.

\section{Aerobic capacity i.e. $\mathrm{VO}_{2} \max$}

The aerobic capacity of women workers in various cashew processing activities is 
depicted in Table 3. Level of physical fitness was good in Cutting of cashew shell 55 percent of majority of the respondents. Vast majority of respondents were in good category of physical fitness i.e. 75 percentages were observed in shelling of cashew nut and Packing of kernel. In drying and cooling of kernel, peeling of kernel, and grading of kernel, respondents were in good category of physical fitness i.e. 80 percent, 70 percent and 85 percent respectively. Vast majority of respondents from total respondents 73 percent respondents were in good category of physical fitness. Whereas 15 percent respondents were in very good category of physical fitness.

Very few i.e.4 percent respondents were in low average category of physical fitness. Only 2 percent of respondents were in poor category of physical fitness. Level of physical fitness was very good in Cutting of cashew shell i.e. 40 percent, in shelling of cashew nut 5 percents respondents were in very good category of physical fitness. Whereas in drying and cooling of kernel and peeling of kernel 10 percent of respondents were in very good category of physical fitness. Grading of kernel and Packing of kernel in both activities 15 percent respondents were in very good category of physical fitness.

Level of physical fitness of women workers were low average i.e. 5 percent in all cashew processing activities and poor (5\%) in shelling of cashew nut and peeling of cashew nut. Level of physical fitness of women workers were excellent i.e. 5 percent. It is the good indicator to improve work capability and efficiency. In this context, aerobic capacity $\left(\mathrm{VO}_{2} \max \right)$ has widely been considered to be a reliable and valid measure of physical (cardio-respiratory) fitness Kanstrup et al., (1991) and endurance; as $\mathrm{VO}_{2}$ max increases, this indicates greater respiratory capacity and thus better cardiorespiratory fitness.

\section{Classification of Blood Pressure (BP)}

\begin{tabular}{|l|l|l|}
\hline Classification & Systolic BP $(\mathbf{m m H g})$ & Diastolic BP $(\mathbf{m m H g})$ \\
\hline Normal & $<120$ & And $<80$ \\
\hline Prehypertension & $120-139$ & Or $80-89$ \\
\hline Stage 1 hypertension & $140-159$ & Or $90-99$ \\
\hline Stage 2 hypertension & $\geq 160$ & Or $\geq 100$ \\
\hline
\end{tabular}

Table.1 Physical characteristics of women worker involved in cashew nut industry

\begin{tabular}{|l|c|}
\hline Parameters & Mean \pm SD \\
\hline Age$(Y r s)$ & $33.65 \pm 5.68$ \\
\hline Height $(\mathbf{c m})$ & $153.27 \pm 3.8$ \\
\hline Weight(Kg) & $45.96 \pm 6.1$ \\
\hline BMI & $19 \pm 2.71$ \\
\hline VO $_{2}$ max $(\mathbf{m l} / \mathbf{k g} / \mathbf{m i n})$ & $36.98 \pm 4.95$ \\
\hline BP-Systolic $(\mathbf{m m ~ H g})$ & $123.45 \pm 7.88$ \\
\hline BP-Diastolic $(\mathbf{m m ~ H g})$ & $81.12 \pm 6.81$ \\
\hline
\end{tabular}


Table.2 Percentage distribution of cashew processing respondents as per body mass index

\begin{tabular}{|c|c|c|c|c|c|c|c|}
\hline $\begin{array}{l}\text { Presumptive diagnosis } \\
\text { and } \\
\text { BMI class }\end{array}$ & $\begin{array}{l}\text { Cutting o } \\
\text { cashew } \\
\text { nut }\end{array}$ & $\begin{array}{l}\text { Separation } \\
\text { of cashew } \\
\text { nut }\end{array}$ & $\begin{array}{l}\text { Drying and } \\
\text { cooling of } \\
\text { kernel }\end{array}$ & $\begin{array}{l}\text { Peeling } \\
\text { of kernel }\end{array}$ & $\begin{array}{l}\text { Grading } \\
\text { of kernel }\end{array}$ & $\begin{array}{l}\text { Packing } \\
\text { of kernel }\end{array}$ & $\begin{array}{l}\text { Total } \\
n=120\end{array}$ \\
\hline & $\%$ & $\%$ & $\%$ & $\%$ & $\%$ & $\%$ & $\%$ \\
\hline CED Gr. III(Severe)16.0 & 0 & 10 & 0 & 20 & 15 & 5 & 8.3 \\
\hline CED Gr. II(Moderate) 16 - 17 & 15 & 10 & 5 & 10 & 5 & 0 & 7.5 \\
\hline CED Gr.I (Mild) 17.0 -18.5 & 35 & 10 & 20 & 10 & 15 & 30 & 20 \\
\hline Weight normal 20-25.0 & 50 & 60 & 70 & 50 & 60 & 65 & 59 \\
\hline Obese (Grade I) $25.0-30.0$ & 0 & 10 & 5 & 10 & 5 & 0 & 5 \\
\hline Total & 20 & 20 & 20 & 20 & 20 & 20 & 120 \\
\hline
\end{tabular}

Table.3 Percentage distribution of cashew processing respondents as per of $\mathrm{VO}_{2}$ max

\begin{tabular}{|c|c|c|c|c|c|c|c|}
\hline $\begin{array}{l}\text { VO2 } \max (\mathrm{ml} / \mathrm{kg} / \mathrm{min}) \\
\text { Level of physical fitness }\end{array}$ & $\begin{array}{l}\text { Cutting } \\
\text { of } \\
\text { cashew } \\
\text { nut }\end{array}$ & $\begin{array}{l}\text { Shelling } \\
\text { of } \\
\text { cashew } \\
\text { nut }\end{array}$ & $\begin{array}{l}\text { Drying } \\
\text { and } \\
\text { cooling of } \\
\text { kernel }\end{array}$ & $\begin{array}{l}\text { Peeling } \\
\text { of kernel }\end{array}$ & $\begin{array}{l}\text { Grading } \\
\text { of kernel }\end{array}$ & $\begin{array}{l}\text { Packing } \\
\text { of kernel }\end{array}$ & $\begin{array}{l}\text { Total } \\
n=120\end{array}$ \\
\hline & $\%$ & $\%$ & $\%$ & $\%$ & $\%$ & $\%$ & $\%$ \\
\hline Up to 15.0 Poor & 0 & 5 & 0 & 5 & 0 & 0 & 2 \\
\hline $16-25$ Low average & 5 & 5 & 5 & 5 & 0 & 5 & 4 \\
\hline 31- 40 Good & 55 & 75 & 80 & 70 & 85 & 75 & 73 \\
\hline 41-45 Very good & 40 & 5 & 15 & 10 & 10 & 15 & 15 \\
\hline Beyond 45 Excellent & 0 & 10 & 0 & 10 & 5 & 5 & 5 \\
\hline Total & 20 & 20 & 20 & 20 & 20 & 20 & 120 \\
\hline
\end{tabular}

Table.4 Percentage distribution of cashew processing respondents as per blood pressure

$\mathrm{n}=20$ in each activity

\begin{tabular}{|c|c|c|c|c|c|c|c|c|}
\hline $\begin{array}{l}\text { Blood Pressure, } \\
\text { mm Hg }\end{array}$ & $\begin{array}{l}\text { Cutting } \\
\text { of } \\
\text { cashew } \\
\text { Shell }\end{array}$ & $\begin{array}{l}\text { Shelling } \\
\text { of } \\
\text { cashew } \\
\text { nut }\end{array}$ & $\begin{array}{l}\text { Cutting } \\
\text { of } \\
\text { cashew } \\
\text { nut }\end{array}$ & $\begin{array}{l}\text { Drying } \\
\text { and } \\
\text { cooling of } \\
\text { kernel }\end{array}$ & $\begin{array}{l}\text { Peeling } \\
\text { of kernel }\end{array}$ & $\begin{array}{l}\text { Grading } \\
\text { of kernel }\end{array}$ & $\begin{array}{l}\text { Packing } \\
\text { of } \\
\text { kernel }\end{array}$ & $\begin{array}{l}\text { Total } \\
\mathbf{n} \\
=120\end{array}$ \\
\hline & $\%$ & $\%$ & $\%$ & $\%$ & $\%$ & $\%$ & $\%$ & \\
\hline $\begin{array}{l}\text { Systolic } \\
\text { Pre hypertension } \\
\text { (SBP 120-139) }\end{array}$ & 100 & 85 & 100 & 95 & 90 & 90 & 100 & 93.33 \\
\hline $\begin{array}{l}\text { Stage } 1 \text { HTN } \\
\text { (SBP 140-159) }\end{array}$ & 0 & 15 & 0 & 2 & 10 & 10 & 0 & 6.66 \\
\hline $\begin{array}{l}\text { Diastolic } \\
\text { Normal (DBP 60- } \\
\text { 79) }\end{array}$ & 30 & 25 & 30 & 20 & 25 & 15 & 25 & 23 \\
\hline $\begin{array}{l}\text { Pre hypertension } \\
\text { (DBP 80-89) }\end{array}$ & 55 & 55 & 55 & 65 & 55 & 55 & 60 & 57.5 \\
\hline $\begin{array}{l}\text { Stage } 1 \text { HTN } \\
\text { (DBP 90-99) }\end{array}$ & 15 & 20 & 15 & 15 & 20 & 25 & 15 & 18.3 \\
\hline
\end{tabular}

SBP-Systolic blood pressure, DBP-Diastolic blood pressure, HTN-Hypertension 


\section{Blood pressure}

Record of blood pressure was depicted in table 4. Data revealed that systolic blood pressure of hundred percent respondents falls in pre hypertension category in activity of cutting of cashew shell and packing of kernel followed by peeling of kernel, cooling of kernel and grading of kernel 90 percent of respondents were in pre hypertension category of blood pressure. Overall 93 percent of respondents were in pre hypertension category. In the activity of shelling of cashew nut 85percent respondents were in pre hypertension category. Whereas diastolic blood pressure of vast majority of the respondents i.e. 57 percent were in category of pre hypertension and near about one fourth of the respondents i.e. 23 percent were in normal category of blood pressure. 18 percent of the respondents were observed in stage one hypertension category.

However, the results of the study showed that changes in systolic and diastolic blood pressure, as recorded, were not associated with the earlier findings of Astrand (1960) and Kanstru et al., (1991). In the investigation, both systolic and diastolic blood pressures were found to be lower in fisherwomen these results were contradictory with present results, among which only diastolic pressure showed significant differences in subjects this results were in line with present result.

Cashew nut attracts the people of all categories and all over the world. Probable reasons for that it's pleasant taste and nutritive values. Women are the main working population in cashew nut units in Konkan region. Therefore there should be job demand and physical fitness compatibility to improve the health status of women worker so that they can perform their activities more efficiently which will increase more productivity. Physical Fitness Index indicates the individual's status of health and it provides healthy impact on cardio-respiratory system. It can be defined as the ability of an individual to perform a given task in a specified time without any undue stress and fatigue. Many Studies revealed that women were exploited without any consideration of workload demands, physical fitness and nutritional status as they performed dual role of bread earner and home maker

After studying health and nutritional aspects of the women worker involved in selected activity of cashew nut units can be said that the physical level of the women worker was of low average conclusion can be drawn as the physical fitness of women involved in cashew nut factory are less satisfactory may be due to normal nutritional status, heavy workload, less resting allowance etc and which can be improved by providing ergonomically designed tools, work layout and by organizing campaigns like nutritional awareness, by work place guideline to improve work efficiency and to reduce risk factors causing hazards by family resource management etc among these cashew processing workers.

\section{References}

Ahonen, E., Venalainen M, Kononen U, Klen T. 1990. The physical strain of dairy farming. Ergonomics; 33(12):15491555.

Astrand, P.O., Rodahl K, and Dahl H, Stromme S. 1960. Test book of work Physiology. 4th ed., Human Kinetics: 281.

Borah, R, Kalita M. 2001. Identifying drudgery prone home activities in rural areas of upper Bhahmaputra valley zone of Assam. Stud Home Com Sci,; 5(3):165-168. 
Borah, S. and Baruah, M., 2016. Physical fitness of women workers involved in cashew nut factory in Meghalaya, International Journal of Physical Education, Sports and Health 3(1): 13

Borah, S., 2015. Ergonomic assessment of drudgery of women worker involved in cashew nut processing factory in Meghalaya, India. 6th International Conference on Applied Human Factors and Ergonomics and the Affiliated Conferences, Procedia Manufacturing. 3:4665 - 4672.

Garrow, J. S. and Webster, J. 1985. Quetelet's index $(\mathrm{W} / \mathrm{H} 2)$ as a measure of fatness. IntJ7 Obes 9: 147-53.

Kanstrup, $\quad$ L. J. Marving, P.F. HøilundCarlsen, B. Saltin, 1991. Left ventricular response upon exercise with trained and detrained leg muscles Sc and J Med Sci Sports, 1 (2), pp. 112118

Ranjwan SR, Zend, J.P., 2007. Health status of women employed in unorganized self-employed sector. Journals of Dairying, Foods and Home Science. 2007, 26(3\&4).

Sengupta, P S. Sahoo, A., 2011. Fitness assessment study among young fishermen of coastal areas of West Bengal, India South East Asia J Public Health, 1 (2) (2011), pp. 6-14

Varghese, M.A., Saha, P.N. and Atreya, N. (1994). A rapid appraisal of occupational workload from, a modified scale of perceived exertion, Ergonomics, 37 (3), 485-491.

www.clevelandclinicmeded.com/medicalpubs /diseasemanagement/.../arterialhypertensio...assesed on $13 / 6 / 18$ at $4.55 \mathrm{pm}$

\section{How to cite this article:}

Geetanjali Waikar and Suman Singh. 2018. Health Status of Women Workers Involved in Cashew Processing Units in Konkan Region of Maharashtra, India. Int.J.Curr.Microbiol.App.Sci. 7(08): 1745-1751. doi: https://doi.org/10.20546/ijcmas.2018.708.199 